\title{
LEARNING TO READ USING A FAIRY TALE
}

\author{
Azhar Omurzakova \\ Astana International University, Nur-Sultan, Kazakhstan \\ ORCID ${ }^{\text {ID }: 0000-0002-0839-234 X ~}$
}

\begin{abstract}
The article examines the process of teaching a foreign language on the basis of fairy tales. The important advantages of fairy tales as linguodidactic material are authenticity, informative richness, concentration of linguistic means, and emotional impact on the addressee. There are several stages of work on the text of a fairy tale: before text, text, after text. At each of them, it is necessary to use various tasks that contribute to the expansion of the vocabulary of students, increase the level of proficiency in a foreign language, and contribute to the solution of linguistic and cultural problems.
\end{abstract}

\section{INTRODUCTION}

The educational goal of teaching foreign languages is that students master a second language, new means for expressing thoughts. From the first lessons, the teacher draws the students' attention to the difference between the sounds of the native language and the foreign one. Students get acquainted with new grammatical phenomena; expand their ideas about the formation of words. Already at the initial stage, the study of a foreign language activates the work of the auditory, visual, speech, motor, motor analyzers and makes a great contribution to the development of memory, imagination, ideas. Learning a foreign language helps broaden the horizons of listeners, introduces native speakers of the target language to the culture. Most of the students start learning a foreign language with interest. Its study forms the ability to carry out communication, which is the basis in the establishment of correct, good relations in a team. Learning to read is also of great educational value, which contributes to the acquisition of the ability to carefully read words, sentences, and text.

A fairy tale, as a means of teaching, in a foreign language lesson also has enormous educational potential. A fairy tale is always an unobtrusive upbringing. In her best images, she reveals to the listener the world, the essence of human relations, the nuances of human feelings - kindness, respect, sympathy, comradeship, justice, responsiveness, mutual understanding - and thus carries a rich moral potential, revealing some features of the mentality of the representatives of that nation, on the language of which it is written. The tale, which is always interesting to listeners in its content, greatly contributes to the creation of motivation for mastering a foreign language. The widespread use of fairy tales, first of all, contributes to the formation of linguistic competence of students and expands their active vocabulary. A fairy tale is a poetic fiction. However, this basic principle of the artistic method by no means denies its connection with reality, which determines the ideological content of the tale, the nature of the plot, images, and details of the narrative. Fiction in a fairy tale is built, as a rule, on a completely definite ground based on reality. Each fairy tale, no matter how fantastic it may be filled, draws realistic pictures of the life of the people. Therefore, a fairy tale is precisely that fertile literary material that contributes to the further interest of students in the study of more serious literary works (stories, essays, short stories) intended for home reading.

Fairy tales are an excellent means of introducing children to the culture of various nations, the development of speech. Fairy tales in English turn the learning process into an exciting game. The lessons can be used with fairy tales of different peoples of the world. In many fairy tales, there is a typical folklore technique - repetition. Each subsequent episode is enriched with a new detail and almost literally repeats the previous one, this allows you to recognize words and gradually develop the skill of perceiving the text, which greatly facilitates the learning process itself. Reading Fairy 
Tales contributes to the formation of intelligence, sharpening of feelings, the development of cognitive processes and the general culture of younger students.

Work on reading and dramatizing literary works that correspond to the age characteristics of students, stimulates the development of children's creative imagination, the development of individual abilities, creativity, expansion of vocabulary, imaginative and associative thinking, selfexpression, enrichment of the inner spiritual world of the student. It is especially important to give students a visual idea of the life, traditions, and linguistic realities of English-speaking countries. To fulfill this goal, fairy tales can serve that contribute to the implementation of the basic requirement of the communicative methodology "to present the process of mastering a language as comprehension of a living foreign language reality" [Didactic potential of the fairy tale as a means of teaching English in primary school].

Fairy tales contribute to a child's social and emotional development. A relaxed, positive environment is established between the narrator and the listener. Each individual tale may have a special dramatization technique. You can imagine a fairy tale as a puppet theater, Paper Theater, play it on a drawn TV, or dress up children in masks. Reading fairy tales helps to expand the vocabulary of students, the study of speech patterns and stable expressions. Fairy tales help students adapt to the language, learn to read fluently. In elementary school, it is best to engage in reading with a teacher. In elementary school, fairy tales can play an important role in vocabulary learning. Learning with fairy-tale characters is fun and instructive for kids [Knyazeva T.A., 2013].

For the formation of reading skills, I propose the following universal algorithm for working on a fairy tale.

\section{Pre -reading}

The teacher tells the name of the tale, which the students are now about to read, and also invites them to guess what it will be about. Further, the teacher introduces new lexical material, which will be necessary for the subsequent understanding of the tale and is intended for active possession. New lexical units are introduced before reading each part of the tale. Special attention is paid to phrase logical units; a regional geographic commentary is carried out. Options for pre-text exercises:

- Given two columns, the student's task is to connect the pairs: word and definition.

- Write the antonym or synonym for the new word: large - big, large - small.

- Choose a suitable synonym from the proposed options: can't stand - to love, to hate, to stand.

- Connect pairs of words that are appropriate in meaning - form phrases: Match the animals with the places they live in: a fox, a dog, a tiger - a zoo, a forest, a house.

\section{Reading}

Perception of the tale in parts. Before reading each part, the teacher instructs the students:

- Who is the main character

- How we feel about him

- What did he do

\section{Checking the understanding of the general content of the tale.}

Students first answer the questions posed to the teacher before reading. The following exercises may then be suggested, which can be done either orally or in writing:

- Choose the correct answer

- Divide the tale into parts and head each of them

- Find or write out sentences that express the main idea of each separate part of the text;

- Find situations in which the following expressions have been used;

- Indicate which of the characters is the author of the following phrases

- List in order all the characters in the tale;

- Name in order all the places of action that were mentioned in the text;

- Arrange parts / sentences in a logical sequence

- Arrange the pictures in the correct order, in accordance with the events in the fairy tale.

- Mark which statements are true and which are not

- Correct errors in statements; 
- Choose those pictures that correspond to the plot of the tale;

- Compare the Russian and English versions of the tale.

\section{4 . Post -reading}

Development of skills and abilities of oral speech. Communicative speaking can be stimulated with a variety of activities:

- describe the main character of the tale

- play out the dialogues of the heroes

- comment on this or that action or behavior of the hero

- what phrases, idioms can be used when describing a hero

Thus, the use of fairy tales in English lessons when teaching reading brings variety to the content of the lessons, broadens the horizons of students, increases their communicative culture, allows them to develop a linguistic guess and sense of language, significantly increases interest in the language itself, and, consequently, increases motivation to learn. ... Without a doubt, the use of fairy tales in the classroom improves the process of learning a foreign language. A fairy tale, like any other element of the communicative method of teaching language, diversifies classes and allows students to study the necessary information in a simple and entertaining way, and develop various language skills. But it must be remembered that the efficiency of using a fairy tale in teaching English is influenced by the rationality of the organization of classes.

In teaching a foreign language, reading should not be the main activity; reading should be used as a support to activate spoken language. However, being able to read fluently and correctly is essential to learning English successfully. Reading by roles is an excellent preparation for dramatizing a fairy tale - one of the main methods of teaching speaking. In this regard, reading should be given special attention and time should not be spared for it. This is especially true at the initial stage of teaching a foreign language. For the development of reading skills within the framework of the theme "Family", you can suggest the use of the fairy tale Little Red Riding Hood.

Little Red Riding Hood:

Little Red Riding Hood lived in a wood with her mother. One day Little Red Riding Hood went to visit her granny. She had a nice cake in her basket. On her way Little Red Riding Hood met a wolf. "Hello!" said the wolf. "Where are you going?" "I'm going to see my grandmother. She lives in a house behind those trees." The wolf ran to Granny's house and ate Granny up. He got into Granny's bed. A little later, Little Red Riding. Hood reached the house. She looked at the wolf. "Granny, what big eyes you have!" "All the better to see you with!" said the wolf. "Granny, what big ears you have!" "All the better to hear you with!" said the wolf. "Granny, what a big nose you have!" "All the better to smell you with!" said the wolf. "Granny, what big teeth you have!" "All the better to eat you with!" shouted the wolf. A woodcutter was in the wood. He heard a loud scream and ran to the house. The woodcutter hit the wolf over the head. The wolf opened his mouth wide and shouted and Granny jumped out. The wolf ran away and Little Red Riding Hood never saw the wolf again. [British Council official website]

Students are encouraged to read the story on their own. In the lesson, the teacher begins reading a fairy tale. As the teacher progresses, the teacher stops and one of the students continues reading aloud. Everyone else follows the text and listens carefully, because the student can stop at any time and invite any student to continue reading at his discretion. Next, the teacher offers students tasks to test their understanding of the text. For example, combine pictures with characters with their names in English. Then the teacher divides the students into groups, each group is given a set of cards with random passages of text and pictures. The task of the students is to read aloud the passage of the text, the action of which is shown in the picture and arrange them in the order they should be in the plot. (see Appendix 1)

Thus, with the help of a fairy tale, the reading skill can be developed, which is a means of teaching speaking. The use of such fabulous folklore in English lessons is also aimed at increasing the effectiveness of students' activities. The use of fairy tales contributes to the formation of the linguistic competence of students. The content of the texts of fairy tales helps to expand students' active vocabulary. They help unload the consciousness of students, remove negative emotions, and 
create a favorable friendly atmosphere of communication in the lesson, which is necessary in the classroom for both the teacher and the student. Fairy tales are also one of the important means of moral education of the individual. By the example of the heroes of a fairy tale, for example, a wolf, children learn that cheating is not good. In fairy tales, descriptions of the noble deeds of the main characters are often found. Thus, using the fairy tale "Little Red Riding Hood" as an example, children see how a lumberjack saves a grandmother and a girl from an evil wolf. Reading the tales of foreign authors and peoples realizes the development of such universal educational actions described in the Federal State Educational Standard, such as:

- acquaintance with the world of foreign peers using the means of the studied foreign language (through children's folklore, some samples of children's fiction, traditions)

- knowledge of small pieces of children's folklore (poems, songs); knowledge of the elementary norms of speech and non-speech behavior, adopted in the country of the target language [Fairy tales as an initial stage of learning to read in a foreign language].

The teacher can also use the following technique while learning to read: towards the end of the lesson, he begins to read a fairy tale in Russian and stops his story at the most interesting place. The student, because he is interested and passionate, will undoubtedly want to know the continuation of the story. Then the teacher invites him to finish reading the story at home on his own, but already in English, occasionally glancing at the translation. Thanks to English fairy tales and their translation, you can conduct fun and exciting activities. Students will no longer perceive such lessons as an ordinary regular lesson. It will be an exciting journey to the magical world for them. Moreover, a separate advantage of reading fairy tales is that the student memorizes words and fixed phrases at a subconscious level, without memorizing them. Fascinating plots, magical characters contribute to adaptation to the language and expanding the stock of English words.

The article considered a fairy tale in English lessons from the point of view of a means for forming reading and aspects of the language. There are various approaches, methods and techniques in teaching English. We have touched on one of the unconventional techniques - teaching through a fairy tale. The use of a fairy tale contributes to the most solid memorization of grammatical structures and lexical units, which will subsequently make it possible to correctly use any structure in speech. In the future, we plan to further research this topic.

\section{REFERENCES:}

Didactic potential of the fairy tale as a means of teaching English in primary school http://elar.uspu.ru/bitstream/uspu/2962/1/02Cherkasova2.pdf

Knyazeva T.A. (2013) Fairy tales and games at the lessons of the English language as an effective method of forming the skills of the language competence of students at the initial stage of training [Electronic resource]. https://nsportal.ru/shkola/inostrannye-yazyki/angliiskiyyazyk/library/2013/06/23/skazki-i-igry-na-urokakh-angliyskogo

British Council official website [Electronic resource].

https://learnenglishkids.britishcouncil.org/ru/short-stories/little-red-riding-hood

Fairy tales as an initial stage of learning to read in a foreign language. https://cyberleninka.ru/article/n/skazki-kak-nachalnyy-etap-obucheniya-chteniyu-nainostrannom-yazyke/viewer

\section{APPENDIX 1}

\section{Materials for the fairy tale "Little Red Riding Hood" and exercises for teaching reading}

\section{Card1.}

"Granny, what a big nose you have!" 
"All the better to smell you with!" said the wolf.

\section{Card2.}

Little Red Riding Hood went to visit her granny.

On her way she met a wolf.

\section{Card3.}

The woodcutter hit the wolf and Granny jumped out.

Little Red Riding Hood never saw the wolf again.

\section{Card4.}

"Granny, what big eyes you have!"

“All the better to see you with!" said the wolf.

\section{Card5.}

"Granny, what big teeth you have!"

"All the better to eat you with!" shouted the wolf.

\section{Card6.}

The wolf ran to Granny's house and ate Granny up.

He got into Granny's bed.

\section{Card7.}

"Granny, what big ears you have!"

"All the better to hear you with!" said the wolf. 